\title{
Instructional Planning and Evaluation Techniques Used by Teachers for their Students with Special Needs
}

\author{
Prof. Dr. Shahida Sajjad (Author) \\ Dean Faculty of Social Sciences, Malir University of Sciences \& Technology, Karachi \\ Address: A - 12, Block 4, Gulistan e Jauhar, Karachi - 75290 \\ Dr. Saira Saleem (Co- Author \& Corresponding Author) \\ Assistant Professor Department of Special Education, University of Karachi \\ Sheikh Zayed Islamic Research Centre, Special Education University of Karachi \\ Ms. Fouzia Rehman (Co-Author) \\ M.Phil. Scholar, Department of Special Education, University of Karachi \\ Address: R-15, $2^{\text {nd }}$ floor, St - 7, Block E 10/A, Gulshan e Iqbal Karachi
}

\begin{abstract}
This empirical study aimed to explore how teachers plan instructions for their students with special needs. Fifty teachers were selected through purposive sampling who were teaching students with hearing impairment, and students with visual impairment at class eighth, ninth and tenth level in special schools of Karachi city. The data collected through a checklist was analyzed through descriptive statistics and One-way Analysis Of Variance (ANOVA). The findings of the study reveals that majority of the teachers always assess students with special needs, include activities in curriculum, plan curriculum according to special needs of students, complete their syllabus in time and carefully plan students' assignments. Majority of the teachers use teacher-made test for evaluating their students with special needs.
\end{abstract}

Key words: Instructional Planning, Evaluation Techniques, Students with Special Needs

\section{Introduction}

The aims of education for all the students are same but how the education is imparted to them may be different for students with and without special needs. While teaching students with special needs the instructional planning is carried out by their teachers who should consider some factors in instructional planning depending upon the special needs of students caused by their disabilities. These factors may include (but not limited):

- Identification of special needs of students with disability which is the first step of learning process and all further planning is based on this step. These special needs vary from student to student according to the disability and further vary from student to student even having the same disability because of the severity of the disability, and age of onset.

- Inclusion of different activities in curriculum of students with special students thus making the lessons interesting, meaningful and easy to understand.

- Planning of Curriculum according to special needs identified at first step.

- Completion of syllabus by teachers in time to carry out evaluation of learning.

- Planning of students' assignment carefully to get a feedback on what the students have learnt and if their progress is satisfactory or not.

Teaching students is not the only aim of education but how the teacher has performed and what students have learnt is equally important. Using different techniques of evaluation by teachers can serve this purpose. Evaluation could be formative that is continuously done throughout the teaching/learning process or it could be summative that is carried out after completing the syllabus. Teachers may rely on different techniques of evaluation including; teacher-made tests, self-assessment tests and performance tests. The teacher made tests are non-standardized tests designed by teachers based on different units included in the syllabus to find out if the 
objectives of learning are achieved or not. Self-Assessment enable students to identify their own strengths and weaknesses for a better sense of understanding of their own learning. A performance test is used to assesses performance of students in different areas of curriculum e.g., through solving a math's problem.

Since every test has its own limitations as well as advantages, therefore it is good to use a combination of different techniques to overcome the short comings of using a single technique. The present study aimed to find out the factors considered by teachers while planning instructions for their students with special needs. The study further intended to explore the different techniques used by teachers to evaluate learning of their students with special needs.

\section{Review of Literature}

A number of research studies confirmed the importance effective instructions for the success of students (Bright, 2011; Downey, Steffy, English, Frase, \& Poston, 2004). There are many factors that need to be considered by a teacher while planning instructions for their students with special needs e.g., assessment of special needs of students, including activities in curriculum to make lesson more interesting and easier to understand, planning curriculum according to special needs of students, and planning of students' assignment carefully. Researchers emphasized on continuous assessment of students for their grouping and making instructional decisions (Moon, 2005; Tomlinson, 2001). Brookhart and Lazarus argued the importance of assessment for effectively learning of students through their involvement in the process of learning. Assignment is a device used to improve performance of students and to develop their study skills, self-regulation, school engagement, discipline, and responsibility (Cooper, Robinson, \& Patall, 2006; Buijs \& Admiraal, 2013). Evaluation can be used to assess the performance of students, performance of teachers and efficiency of education system to improve it (Government of Pakistan, 2009).

There are very few studies conducted in Pakistan about the instructional plans used by teachers for their students with special needs and the different techniques used by teachers to evaluate performance of their students with special needs.

\section{Research Method}

The present study was descriptive and quantitative in nature and was carried out to explore the instructional planning methods used by teachers for their students with special needs and different techniques used by them to evaluate learning of their students with special needs.

\subsection{Population and Sample}

All teachers who were teaching students with hearing impairment, and students with visual impairment at class eight, ninth and tenth level in special schools of Karachi city constitute the population of the present study. A sample of ten special schools was selected through purposive sampling. Fifty teachers (five from each school) who were teaching students with hearing impairment, and students with visual impairment at class eight, ninth and tenth level were selected through purposive sampling method. The group of teachers was the independent variable of the study

\subsubsection{Demographic Characteristics of Sample}

As shown in table 1, there were 45 female teachers and only 05 male teachers in a sample of 50 respondents. There was no gender discrimination among selection of sample but there were lesser number of male teachers as compared to female teachers in teaching of students with special needs in Karachi. Most of the teachers were less than 30 years old and qualification wise mostly were having a master's degree in special education. 
Table 1. Demographic Characteristics of Teachers $(\mathrm{N}=50)$

\begin{tabular}{|c|c|c|c|c|}
\hline \multicolumn{2}{|c|}{ Demographic Characteristics of Teachers } & \multicolumn{2}{|c|}{ Gender } & \multirow[t]{2}{*}{ Total } \\
\hline & & Female & Male & \\
\hline \multirow{4}{*}{ Age in year } & Below 30 & 30 & 2 & 30 \\
\hline & 30 to 39 & 09 & 1 & 10 \\
\hline & 40 to 49 & 5 & 2 & 8 \\
\hline & Above 50 & 1 & 0 & 2 \\
\hline \multirow{3}{*}{ Qualification } & Graduate & 2 & 0 & 2 \\
\hline & Masters in another field & 8 & 0 & 8 \\
\hline & Master's in special education & 35 & 5 & 40 \\
\hline
\end{tabular}

\subsection{Description of Instruments}

The instrument of the study was a checklist used to find out as the instructional plans and different evaluation techniques used by teachers in teaching/learning process of students with special needs. The instrument was designed based on literature review and a research conducted in the field of special education (Bano \& Aziz, 2012). The use of instructional plans by teacher was measured through five factors (dependent variables) including: assessing special needs of students, designing curriculum according to special needs of students, including activities based on special needs of students in curriculum, completion of syllabus by teachers in time and planning of students' assignment carefully. There were three different evaluation techniques (dependent variables) used by teachers including: teacher-made tests, self-assessment tests and performance tests.

Table 2 shows the score of Cronbach's Alpha as 0.934 which is a very good sign of the reliability of the instrument used to collect data in present study and hence the results can be generalized in the field.

Table 2. Reliability Statistics

\begin{tabular}{|c|l|}
\hline \multicolumn{2}{|c|}{ Reliability Statistics } \\
\hline Cronbach's Alpha & N of Items \\
\hline .934 & 8 \\
\hline
\end{tabular}

\subsection{Data Collection and Analysis}

The data was collected by personally visiting the special schools with prior permission and getting the responses to be filled by the teachers on the spot. The process of data collection took a period of almost one months. Descriptive statistics was used for data analysis through SPSS version 21. The One-way Analysis Of Variance (ANOVA) at 0.05 level of significance was used to determine whether there are any statistically significant differences between the means of independent variables or not.

\section{Findings}

The study was based on four research questions and the results are given in tables 3-6 given below:

Research question1: What factors are included in instructional planning for the students with special needs by their teachers?

Table 3 shows five factors of instructional planning for the students with special needs considered by their teachers including; assessment of students with special needs, designing curriculum according to special needs of 
students, including activities in curriculum according to special needs, completion of syllabus in time and planning students' assignments.

Table 3. Factors of Instructional planning $(\mathrm{N}=50)$

\begin{tabular}{|c|c|c|c|c|c|}
\hline Responses & $\begin{array}{c}\text { Always } \\
\text { N\% }\end{array}$ & $\begin{array}{c}\text { Sometimes } \\
\mathrm{N} \%\end{array}$ & $\begin{array}{l}\text { Never } \\
\mathrm{N} \%\end{array}$ & Mean & $\begin{array}{l}\text { Standard Deviation } \\
\text { (SD) }\end{array}$ \\
\hline Special need assessment of students & $34(68)$ & $16(32)$ & Zero $(0)$ & 1.32 & .471 \\
\hline $\begin{array}{l}\text { Designing curriculum according to special needs of } \\
\text { students }\end{array}$ & $36(72)$ & $14(28)$ & Zero $(0)$ & 1.28 & .454 \\
\hline $\begin{array}{l}\text { Including activities in curriculum according to special } \\
\text { needs }\end{array}$ & $34(68)$ & $08(16)$ & $08(16)$ & 1.48 & .762 \\
\hline Completing syllabus in time & $50(100)$ & Zero $(0)$ & Zero $(0)$ & 1.00 & .000 \\
\hline Carefully plans student assignments & $42(84)$ & $8(16)$ & Zero (0) & 1.16 & .370 \\
\hline
\end{tabular}

Table 3 shows that majority of the teachers (68\%) "always"; assess students with special needs (mean 1.32, SD 0.471 ), majority of the teachers $(68 \%)$ include activities in curriculum (mean 1.48, SD 0.762 ), majority of the teachers $(72 \%)$ plan curriculum according to special needs of students (mean 1.28, SD.454), and majority of the teachers $(84 \%)$ carefully plan students' assignments (mean 1.16, SD.370). Table 3 also shows that some of the teachers were "sometimes" including all these four factors in instructional planning. It is also illustrated through table 1 that all the teachers (100\%) "always" complete their syllabus in time (mean 1.00, SD .000).

Research question 2: Is there any significance difference among the factors included in instructional planning for the students with special needs?

The results of One-way ANOVA are given below in table 4:

Table 4. Significance difference among the factors included in instructional planning $(\mathrm{N}=50)$

\begin{tabular}{|c|c|c|c|}
\hline \multicolumn{2}{|c|}{ Factors included in instructional planning } & \multirow{2}{*}{$\begin{array}{r}\mathrm{F} \\
14.836\end{array}$} & \multirow{2}{*}{$\begin{array}{l}\text { Sig. } \\
.000\end{array}$} \\
\hline Special need assessment of student & Between Groups & & \\
\hline & Within Groups & & \\
\hline & Total & & \\
\hline \multirow{3}{*}{ Designing curriculum according to special needs of students } & Between Groups & 19.200 & .000 \\
\hline & Within Groups & & \\
\hline & Total & & \\
\hline \multirow{3}{*}{ Including activities in curriculum according to special needs } & Between Groups & 39.382 & .000 \\
\hline & Within Groups & & \\
\hline & Total & & \\
\hline \multirow[t]{3}{*}{ Completing syllabus in time } & Between Groups* & . & . \\
\hline & Within Groups* & & \\
\hline & Total & & \\
\hline \multirow{3}{*}{ Carefully plans student assignments } & Between Groups & 67.200 & .000 \\
\hline & Within Groups & & \\
\hline & Total & & \\
\hline
\end{tabular}

*F and Sig value can not be calculated as Standard deviation is 00 as shown in table 3. 
Table 4 shows that the sig value of each factor is less than 0.05 therefore it is concluded that there was no significance difference among the factors included in instructional planning.

Research question 3: What are the different techniques used by teachers to evaluate their students with special needs.

Table 5. Evaluation techniques used by teachers to evaluate their students with special needs $(\mathrm{N}=50)$

\begin{tabular}{|l|l|l|l|l|l|}
\hline \multicolumn{1}{|c|}{ Responses } & \multicolumn{1}{|c|}{$\begin{array}{c}\text { Always } \\
\mathrm{N} \%\end{array}$} & $\begin{array}{c}\text { Sometimes } \\
\mathrm{N} \%\end{array}$ & $\begin{array}{c}\text { Never } \\
\mathrm{N} \%\end{array}$ & \multicolumn{1}{c|}{ Mean } & \multicolumn{1}{c|}{$\begin{array}{c}\text { Standard } \\
\text { Deviation (SD) }\end{array}$} \\
\hline Teacher-made tests & $42(84)$ & $08(16)$ & Zero (0) & 1.16 & 0.370 \\
\hline Self-assessment tests & $26(52)$ & $18(36)$ & $06(12)$ & 1.60 & 0.700 \\
\hline Performance tests & $36(72)$ & $14(28)$ & Zero (0) & 1.28 & 0.454 \\
\hline
\end{tabular}

Table 5 reflects various evaluation techniques used by teachers including; teacher-made tests, self-assessment tests and performance tests. Table 5 shows that although majority of teachers (84\%) "always" use teacher-made test (mean 1.16, SD.370), majority of teachers (52\%) "always" use self-assessment tests (mean 1.60, SD.700) and majority of teachers (72\%) "always" use performance tests (mean 1.28, SD.454), but the percentage of teachers using teacher-made test was higher as compared to the percentage of teachers using self-assessment tests and performance tests.

Research question 4: Is there any significance difference among the various techniques used by teachers to evaluate their students with special needs?

The results of One-way ANOVA are given below in table 6:

Table 6. Significance difference among evaluation techniques used by teachers $(\mathrm{N}=50)$

\begin{tabular}{|c|c|c|c|}
\hline \multicolumn{2}{|c|}{ Evaluation Techniques } & $\mathrm{F}$ & Sig. \\
\hline \multirow{3}{*}{ Teacher-made tests } & Between Groups & 67.200 & .000 \\
\hline & Within Groups & & \\
\hline & Total & & \\
\hline \multirow{3}{*}{ Self-assessment tests } & Between Groups & 39.864 & .000 \\
\hline & Within Groups & & \\
\hline & Total & & \\
\hline \multirow{4}{*}{ Performance tests } & Between Groups & 19.200 & .000 \\
\hline & Within Groups & & \\
\hline & Total & & \\
\hline & Total & & \\
\hline
\end{tabular}

Table 6 shows that the sig value of each factor is less than 0.05 therefore it is concluded that there was no significance difference among the various techniques used by teachers to evaluate their students with special needs 


\section{Discussion}

The results show that most of teachers always assess students with special needs, include activities in their curriculum, plan curriculum according to special needs of students and carefully plan students' assignments. All of them were completing their syllabus in time, probably this task of completing the syllabus in time is what is expected form all teachers by the school. These findings were consistent with the work of Bano and Aziz (2012); Mogbo (2002); Ozoji (2003); and Nwachukwu (2006) who believed that assessing special needs of students, including activities in curriculum of special students, and curriculum planning according to special needs are crucial for instructional planning. A study by Onwubolu (2005) also mentioned that lack of curriculum planning was the cause of deterring the growth and development of special education in Delta State of USA. Study by KAHVECI (2016) also highlighted the importance of assessing special needs for adaptations and modifications in curriculum.

The results of present study show that mostly teacher made tests and performance tests were used for evaluation of students as compared to self-assessment whereas many research studies show importance of self-assessment for all students (Brown \& Herris, 2013; Zimmerman \& Schunk, 2011), including students with special needs (Butler \& Schnellert, 2015). There should be a combination of methods to evaluate students and teachers should not rely on teacher-made tests and performance tests only as concluded by Michael and Oboegbulem (2013) in a study conducted in the field of special education.

\section{Conclusion}

The present study reveals that majority of the teachers always assess students with special needs, include activities in curriculum, plan curriculum according to special needs of students, complete their syllabus in time, carefully plan students' assignments in their instructional planning process. It was further concluded that most of the teachers always use all three types of assessments i.e., teacher-made test, self-assessment and performance tests but the percentage of teachers using teacher-made test was higher as compared to the percentage of teachers using self-assessment tests and performance tests.

\section{Recommendations}

Based on the results of present study, it can be recommended that there is a need to have link among different professionals involved in providing services to students with special needs. Schools should provide training to their teachers for their capacity building to use variety of instructional planning and evaluation techniques. Examination standards should be designed to test knowledge of a student rather than measuring their memory.

\section{References}

Bano, U., \& Aziz, H. (2012). Teaching styles of special education teachers at College level. Pakistan Journal of Special Education, 13, 151-162.

Bright, N. (2011). Five habits of highly effective teachers: A role for administrators. The School Administrator, 68(9), 33-35.

Brookhart, S. \& Lazarus, S. (2017). Formative assessment for students with disabilities. Washington, DC: Council of Chief State School Officers.

Brown, G. T. L., \& Harris, L. R. (2013). Student self-assessment. In handbook of research on classroom assessment, 367-393, by J. H. McMillan (Ed.), SAGE Los Angeles: Sage.

Buijs M., Admiraal, W. (2013). Homework assignments to enhance student engagement in secondary education. Eur. J. Psychol. Educ, 28, 767-779.

Butler, D. \& Leyton, S. (2015). Success for students with learning disabilities: What does self-regulation have to do with it? In Self-regulated learning interventions with at-risk youth: Enhancing adaptability, performance, and wellbeing 89-111, by T. Cleary (Ed.). Washington DC: APA Press.

Cooper, H., Robinson J., \& Patall, E. (2006). Does homework improve academic achievement? A synthesis of research, 1987-2003. Rev. Educ. Res, 76, 1-62.

Downey, C., Steffy, B., English, F., Frase, L., \& Poston, W. (2004). The three-minute classroom walkthrough. Thousand Oaks, CA: Corwin.

Government of Pakistan (2009). National Professional Standards for Teachers in Pakistan. Islamabad: Policy and Planning Wing, Ministry of Education. Islamabad: Government of Pakistan. 
KAHVECI, G. (2016). School Counseling And Students With Disabilities. International Online Journal of Primary Education, 5, 15-21.

Michael, E. \& Oboegbulem, A. (2013). Designing Appropriate Curriculum for Special Education in Urban School in Nigeria: Implication for Administrators. US-China Education Review A, 3, 252-258.

Mogbo, I. N. (2002). Restructuring the curriculum of the disabled for self-sustenance, counseling implications. The Journal of National Council for Exceptional Children, 6 , 76-80.

Moon, T. R. (2005). The role of assessment in differentiation. Theory into Practice, 44(3), 226-233.

Nwachukwu, P. O. (2006). Curriculum planning for special needs children: Contemporary issues in special needs education. Journal of the National Council for Exceptional Children, 7, 276-280.

Onwubolu, C. O. (2005). The state and future of special education in Delta state. Paper presented at The Nigerian Primary and Teacher Education Association Conference, FCE (Technical) Asaba.

Ozoji, E. D. (2003). Special education for beginner professionals. Jos: Deka Publications.

Tomlinson, C. A. (2001). How to differentiate instruction in mixed ability classrooms (2nd ed.). Alexandria, VA: Association for Supervision and Curriculum Development.

Zimmerman, B. J., \& Schunk, D. H. (2011). Self-regulated learning and performance: An introduction and overview. In, Handbook of self-regulation of learning and performance, by B. J. Zimmerman \& D. H. Schunk (Eds.), 1-12, New York: Routledge. 